\title{
THE DYNAMICS OF MUHAMMADIYAH'S PRESERVATION AND ITS CHARACTERISTICS IN EDUCATION IN SIKKA DISTRICT, FLORES, NTT'.
}

\author{
Ibnu Mas'ud \\ Ministry of Religious Affairs, Sikka Region, \\ East Nusa Tenggara \\ Jln Wairkalau Sikka NTT No. 27 NTT \\ Email: ibnumasud.jicsa@gmail.com
}

\begin{abstract}
This paper discusses the Muhammadiyah Association in Sikka Flores Regency, East Nusa Tenggara. Because this study is a qualitative study, the authors use an educational approach, a sociological approach and a religious approach as an analysis tool to approach the study in question. The source of scientific data obtained from the management, leaders and cadres Persyarikatan Muhammadiyah in Sikka Regency; school principals, teachers and students at Muhammadiyah schools in Sikka Regency; document; and observations. The instruments used were observation guidelines, interview guidelines, and documentation. Data analysis techniques are data reduction, data display, and data verification. Triangulation is used to test the validity of the data. The researcher came to the conclusion that Muhammadiyah thought had been in contact with Muslim Sikka Regency since 1937, brought by Mr. Husaini Daeng Maramba who came from Selayar, South Sulawesi. Many obstacles faced by Persyarikatan Muhammadiyah Sikka Regency, including: multiple positions, lack of human resources, lack of funds and land, lack of maximum cadre enthusiasm and Muslim awareness of the importance of education are still lacking. Various efforts have been made including: regeneration, withdrawal of contributions,
\end{abstract}


submission of proposals for aid, establishing cooperation, finding land outside Muslim villages, undertaking religious and familial approaches, exemplary, earnest sacrifice, earnest determination and earnest effort, ta'awun between business charity and sincerity are the basis in every movement.

Keywords: Muhammadiyah Association, Business Charity, Muhammadiyah Educational Institution

\section{Introduction}

Muhammadiyah is an Islamic organization engaged in the propaganda mission of amar ma'ruf nahi munkar, having the Islamic faith and originating in the Qur'an and Sunnah. The Muhammadiyah Organization was founded by K.H. Ahmad Dahlan on the 8th Dzulhijah 1330 Hijriyah coincided with the 18 November 1912 militia in the city of Yogyakarta. The purpose of Muhammadiyah's mission is to uphold and uphold the religion of Islam so that a true Islamic society can be realized. The efforts and activities of Muhammadiyah's religious affairs cover the fields of religion, education, social affairs, and the field of political participants who have an orientation in the effort to revive amar ma'ruf nahi mungkar and provide ethical, moral and moral guidance on government and community policies. ${ }^{1}$

Another thing that goes against the movement that K.H. Ahmad Dahlan was a learned man in Makkah and was deeply influenced by the ideas of reforms initiated by Ibn Taimiyyah, Jamal al-Din al-Afgani, Muhammad 'Abduh,

${ }^{1}$ Siti Rajiah Rusydi, Peran Muhammadiyah: Konsep Pendidikan, Usahausaha di Bidang Pendidikan, dan Tokoh, Jurnal Tarbawi| 1 |No date): p. 139. 
Rashid Ridha and Farid Wajdi and Rahmatullah Al-Hindi, ${ }^{2}$ through their writings which increasingly opened up the horizon, inspired him and gave him a strong impetus for reform. ${ }^{3}$ Besides that he also felt very concerned with the increasingly widespread Christianization and the low understanding of Islam among the prijajis. ${ }^{4}$ This condition disturbed his heart and mind to improve the nation's condition.

The same situation was experienced and felt by leaders of Muhammadiyah Sikka Regency. As is the condition of Indonesian Muslims in general and Yogyakarta Muslims in particular, in the early preaching of K.H. Ahmad Dahlan, several decades earlier the condition of Muslims in Sikka Regency was not much different. In terms of education, very few Muslims are educated. That is caused by the low awareness of the importance of education, also because of the lack of educational institutions. Even if there is an educational institution, then it is a Catholic educational institution or educational institution owned by the government but nuanced Catholic.

Seeing the condition of Muslims in Sikka Regency which is very alarming and the experiences and knowledge

${ }^{2}$ Hadjid, Pelajaran KHA. Dablan: Mubammadiyah Falsafah Ajaran \& 17 Kelompok Ayat Al-Qur'an (Warisan Intelektual KHA. Dablan Yang Ditulis Oleh Murid Termudanya) (Cet. III; Yogyakarta: LPI PPM, 2008), p. 3.

${ }^{3}$ Haedar Nashir, Kuliah Kemubammadiyahan 1 (Cet. I; Yogyakarta: Penerbit Suara Muhammadiyah, 2018), p. 69.

${ }^{4}$ Tim Penulis Buku Pedoman AIK, Al-Islam dan Kemuhammadiyahan (Edisi 1; Malang: UMM Press, 2012), p.23-29. 
gained in Java, Sulawesi, Kupang and other areas, encouraged Muslim scholars in Sikka to improve the living conditions of Muslims in the Regency Sikka. In their view, the most effective effort to achieve these goals is education. In order to make educational institutions easy to establish and run, the management of Muhammadiyah for Sikka Regency was formed.

The reason for the interest of researchers to examine Muhammadiyah educational institutions in Sikka Regency is because of the limitations they have, the Muhammadiyah Sikka requirements are able to advance the education of Muslims in Sikka Regency with extraordinary extraordinaryness. Whereas Muslims in Sikka Regency are less than 9 percent and all of them are migrants (Bajo, Buton, Bugis, Makassarese, Muslims from other regencies in NTT, Java, Bima and Padang). Sikka Regency is a district in NT'T where the majority of the population is Catholic (about 91\%) and are very fanatical Catholics.

Maumere as its capital city is nicknamed "The Roman Porch". This nickname is enough to emphasize how the nuances of Catholic religious life in this city. As an illustration of the thick nuances of Catholicism in this city are: very easy to find people who wear cross necklaces or rosaries; the church is scattered everywhere; there are many Catholic schools from kindergarten to tertiary level (high seminary); so

${ }^{5}$ Video Penganugerahan Maarif Award 2018, liputan reporter Metro TV, menit ke 21.49 - 21.51 
often we encounter Catholic rituals or religious events; there are many frateran halls and sisters; there is a huge statue of Jesus Christ, as well as a statue of the Virgin Mary; officials from the Regent, DPR to RT level officials are Catholics, it's easy to find crosses and other Catholic symbols even in public facilities such as in public schools, government hospitals, government offices, stalls selling food with dog ingredients and pigs very much; even dogs and pigs roam freely; public or government events are always interspersed with Catholic rituals; etc.

\section{Research Methodology}

This type of research was conducted through field research using qualitative research models. This research was conducted in the East Nusa Tenggara Sikka Regency with a focus on the development of the Muhammadiyah community, business charity and education in the Muslim minority community of Sikka Regency, so that the scientific study approach that the author uses in this study is the educational approach, sociological approach and religious approach because of the three approaches this is in accordance with the object of the study. Research data obtained from various references in the form of literature, and books that have relevance to the research. The sampling was done by observation, interview and documentation. 


\section{Results and Discussion}

\section{A. Development of Muhammadiyah Society in Sikka Regency}

1. History of the Muhammadiyah Association in Sikka District

Muhammadiyah's thought was first in contact with residents of Sikka Regency in 1937, brought to Geliting (a Muslim village of Makassar, Bugis and Bajo ethnic groups located in Kewapante District, Sikka Regency) by Mr. Husaini Daeng Maramba. He is from Selayar, South Sulawesi). Mr. Husaini Daeng Maramba spread the Muhammadiyah thoughts of ordinary recitals. This continued until 1949 when Muhammadiyah as an organization began to take shape in Sikka District, in the form of the Muhammadiyah Geliting Branch Management, under Selong, East Lombok, West Nusa Tenggara, with the first branch leader being Husaini Daeng Maramba. This is unique because Muhammadiyah in Sikka Regency is organizationally started from the branch leader, not the regional leader. After Husaini Daeng Maramba returned to Selayar, he was succeeded by Abbdurrahman Bin Mahmud.

In 1952 PCM (Muhammadiyah Branch Management) Geliting was established with a Legalization Decree from PP Muhammadiyah, remaining under Selong, East Lombok, West Nusa Tenggara. Abdurrasyid Seho became the first branch chairman from 1952 to 1960 without any business charity. In 1960 he was replaced by Haji Abdul Syukur with a 
structure that had begun to be complete, with a charitable effort to empower the economic community.

In 1985, the first muscab branch was held. At that time, the NTT PWM had been formed and wanted to form Muhammadiyah administrators in the districts in the province of East Nusa Tenggara. Because of that muscab also became musda. Then Musabab was held as well as Musda, then Haji Abdul Syukur was elected as the chairman of PCM Geliting as well as PDM Sikka.

Abah Rasyid and Mr. Mudjir Muchlis as members were assigned to establish PCM and charity ventures. The two Muhammadiyah figures in Sikka Regency immediately lobbied government leaders, religious leaders and community leaders in each village inhabited by the Muslim community. The lobbies conducted by these two figures are not easy. Challenges and obstacles are often experienced. But Abah Rasyid and Pak Mudjir never broke up to continue to fight for the development of the Muhammadiyah Association in Sikka Regency.

Hajjah Rahmania (wife of Haji Abdul Syukur) donated a one hectare land. Then in 1985, on the waqf land was established Muhammadiyah Waipare Middle School, with Mr. Mudjir Muchlis as the school principal. Two years later, in 1987 Muhsadiyah Wuring MTs was established, with Pak Mudjir as the school principal. In 1986, Haji Abdul Syukur as Chairman of PCM Geliting and PDM Sikka endowed his land which is now the place of the Darus Salam mosque, Ummu Hafshoh orphanage and Muhammadiyah High School, 
covering an area of one hectare. and Muhammadiyah Geliting Middle School.

In 1975, Abah Rasyid and Pak Mudjir explored the founding of Muhammadiyah High School. The Department of Education and Culture of Sikka Regency suggested that Muhammadiyah of Sikka Regency establish a high school, while the NT'T PWM wanted the establishment of a SMK. The proposal to establish a Muhammadiyah Vocational School was finally rejected by the Department of Education and Culture in Sikka Regency, so that until now the Muhammadiyah Association of Sikka Regency does not have a single vocational school.

1. Obstacles to the Development of the Muhammadiyah Association in Sikka Regency and the Solution

a. Double Position

One of the shortcomings and constraints experienced by the Muhammadiyah Regency of Sikka Regency is that there are still many concurrent positions in the Muhammadiyah Regency of Sikka. One Muhammadiyah cadre can hold multiple positions, such as a cadre who has served as a PDM administrator but also serves as a PCM, PRM and business charity administrator. One cadre can hold two, three or even four concurrent positions at the same time. This has a bad impact on the development of the company, because the concentration of cadres is divided, so that the work of cadres is not optimal. Realizing that, Muhammadiyah leaders tried to do regeneration and invite 
people who were considered to have potential but were not yet involved in Muhammadiyah requirements to become Muhammadiyah people and administrators.

b. Restricted Human Resources

Another obstacle experienced by Muhammadiyah in Sikka Regency is the lack of cadres. This is due to the very small number of Muslims in Sikka Regency, which is only around nine percent of the total population of Sikka Regency population. The shortage of cadres as the movers and activists of the organization has an impact on the dual positions of management and not the maximum motion of the organization in serving the people.

To resolve this obstacle, the Muhammadiyah organization carried out early regeneration of children who study at Muhammadiyah educational institutions because the Muhammadiyah school is a very effective Persyarikatan cadre media. ${ }^{6}$ Another form of regeneration is sending children to go to school or study in Java, Sulawesi and Kupang. This effort was quite successful despite other obstacles such as a child who dropped out of school and returned to Maumere before completing his education. There is also because the cadres work or become civil servants outside Sikka Regency, even outside the NTT province. Other cadre constraints are after the cadres work or become civil servants in Sikka Regency, some of them

${ }^{6}$ Farid Setiawan, Genologi dan Modernisasi Sistem Pendidikan Muhammadiyah 1911-1942, p. 245. 
are busy with their work, so they cannot do anything for Muhammadiyah.

c. Lack of Funds

The development of Muhammadiyah's Sikka Regency is not optimal because of the lack of funds owned by Persyarikatan. Every activity certainly requires funds. The greater the activity, the greater the funds needed. Lack of funds owned by the company has an impact on the activities carried out by the company only on a small scale in terms of quantity and quality. Even the lack of funds is the cause of the program that has not been implemented.

The lack of funds was overcome by attracting payments from Muhammadiyah cadres and students attending Muhammadiyah schools. But the policy of collecting fees from students is not enforced in all Muhammadiyah schools, but it looks at the condition of the school, students and parents of students. Another way is by submitting proposals for funding requests to various parties, including government, private sector, NGOs and individuals. Another solution is to invite the cooperation of related parties. Aside from the three obstacles, there are actually more such as lack of land and the cadre's enthusiasm in management is still not optimal.

\section{B. Development of Muhammadiyah's Business Charity in Sikka Regency}

Muhammadiyah's charitable efforts are the spirit of Muhammadiyah's missionary struggle so that the existence of 
Muhammadiyah's charitable efforts is an important factor supporting the development of the organization. However, the development of Muhammadiyah's charitable endeavors in Sikka Regency proceeded very slowly due to obstacles encountered. Whereas more and more, the progress and orderliness of Muhammadiyah's charitable efforts will be able to encourage and facilitate the propagation of propagating and grounding the idea of progressing Islam. ${ }^{8}$ The Muhammadiyah Association of Sikka Regency only has a few charity businesses, namely:

\section{Charitable Enterprises in the Social Field}

\section{a. Orphan Housing}

The Muhammadiyah Orphan named Ummul Mukminin Hafsah Orphanage was established in 1993, by Aba Rasyid who was then the chairperson of PDM Sikka with his wife (Siti Mudiyah) who was one of the founders of Aisyiyah Sikka Regency and at that time served as the chairman of Aisyiyah. The establishment of the orphanage was driven by concern over the number of children who were orphaned because their parents were victims of natural disasters and tectonic earthquakes as well as a devastating tsunami that claimed more than two thousand lives on December 12, 1992 in the northern part of Sikka Regency.

7“AUM Berkemajuan Berspirit Al Maun”, Suara Muhammadiyah (Edisi 7, Tahun ke 103. Yogyakart, 1-15 April 2018), p. 7.

8"Misi Penting Amal Usaha Muhammadiyah", Suara Muhammadiyah (Edisi 7, Tahun ke 103. Yogyakart, 1-15 April 2018), p. 6. 
After the disaster, Aba Rasyid visited several islands, including the island of Babi, which was the worst place because there was not a single house that survived the sweeping waves of the tsunami. This policy adopted by Aba Rasyid was driven by the spirit of al-Maun who was ingrained in him. By basing on the spirit of al-Maun, Muhammadiyah became a social and service Persyarikatan such as establishing schools, hospitals and orphanages for the underprivileged, orphans and marginalized people.'

b. Humanity Ship AMCF

AMCF Humanitarian Ship is a ship organized by AMCF (Asian Muslim Charity Foundation) for activities to help people who are on islands and beaches that are difficult to reach. Maumere should be grateful for having this ship, because there are only seven AMCF Humanitarian Ships in Indonesia, including Maumere. The existence of this ship in Maumere is inseparable from the active role of the Muhammadiyah Association of Sikka Regency, which has submitted proposals and continues to lobby the Central AMCF management in Jakarta through PDM chairman Sikka (Ustaz Ihsan) who is also a member of the Central AMCF management.

The biggest obstacle to Muhammadiyah's requirements in Sikka Regency is funding. Whereas in areas that have truly developed Muhammadiyah requirements the

${ }^{9}$ Zuly Qodir, Mubammadiyah Studies: Reorientasi Gerakan dan Pemikiran Memasuki Abad Kedua (Cet. V; Yogyakarta: Kanisius, 2014), p. 36. 
funds for the development of the Muhammadiyah Association are largely supported by charity businesses that are run. This is the source of the lack of funds for the Muhammadiyah Association of Sikka Regency because all this time the Muhammadiyah Association of Sikka Regency has no business charity in the economic field. Most recently PCM Wuring established a simple kiosk that they named "KiosMu" with the business of buying and selling rice from and to members and the community.

\section{Business Charity in the Religious Field}

In the field of religion, although not much has been done by Muhammadiyah, the Muhammadiyah Association of Sikka Regency has built two mosques, namely Muhammadiyah Darussalam Mosque Waioti, and Pangabatang Island Mosque. In addition, Muhammadiyah also managed to build a musala within the Muhammadiyah Wuring MTs and MTs, Muhammadiyah Waipare Junior High School and the Muhammadiyah Parumaan MIS musala. By cooperating with AMCF and Rumah Wakaf, Muhammadiyah placed several preachers in several Muslim villages.

2. Business Charity in the Field of Education Muhammadiyah's charitable endeavors in the field of education are the pride and achievement for the Muhammadiyah Association of Sikka Regency. In the field of education Muhammadiyah is able to establish many educational institutions, ranging from kindergarten, MI, MTs, junior high schools, MA, high schools to tertiary institutions 


\section{Development of Muhammadiyah Educational}

\section{Institutions in Sikka Regency}

1. Obstacles to Development of Muhammadiyah Educational Institutions in Sikka Regency

a. Lack of awareness among the Muslim regarding the importance of Education

The Bajo people, as the biggest contributor to the Muslim population of Sikka Regency, are a tribe that lives in simplicity. They have a philosophy of life, "Ai matakole llau ma mai asked, saloh mene mamie again" Bajo people are a tribe that can not live far from the sea. So that their philosophy of life is also related to the sea and marine products. If interpreted, the philosophy was meant "what we get today (fish) is what we eat, to eat tomorrow, tomorrow can be sought again". For Bajo people, life is as long as they can eat and drink.

The Bajo tribe in Sikka Regency are not much different from even almost the same as their Bajo brothers throughout the world. Their problem is the same, namely the problem of education. The biggest problem for schools in the Bajo tribal community is the problem of dropouts. For Bajo people, school is only to be able to read, write and count. So that the average Bajo children drop out of school when third grade or fourth grade elementary school, when they can already read, write and count.

One characteristic of the Bajo tribe throughout the world is their nomadic life. Bajo people like to move from one beach to another according to the seasons and the ups 
and downs of their fortune. This habit is certainly very influential on the education of Bajo children. With their parents' habit of moving from one place to another, Bajo children will automatically move to another place to follow their parents. This certainly causes Bajo children to often leave the classroom. They will return to school if their family returns to the village where they go to school. This habit is the main cause of Bajo children holding class, even stopping going to school.

\section{b. Existing public schools}

The existence of public schools around Muslim settlements is very closely influential on the development of madrassas, especially Muhammadiyah schools. Muslims who lack religious understanding usually pay less attention to the religious education of their children, so what they pay attention to in choosing a school for their children is the complete or inadequate infrastructure that the school has.

The mistaken understanding of some parents that madrasa graduates only continue their education to madrassas and can only be religious teachers, is something that reinforces the reasons parents send their children to the nearest public schools. The community considers madrasa as a second grade school, so it is a shame to go to madrasa to be another reason to prefer the nearest public school to madrasa.

c. Lack of Public Spaces

As migrants, land is a problem that is often an obstacle for Muslims in Sikka Regency in activities related to public affairs, 
such as building mosques and schools. Many mosques on the mainland of Flores, Sikka Regency are almost without a yard. This is also the case with schools established by Muslims.

Muslims in Sikka Regency live forming communities in small villages which, along with the changing times and rapid population growth, cause Muslim villages to become densely populated villages that often leave no land for public activities, such as sports fields or to set up schools.

1. Strategies Used in the Development of Muhammadiyah Educational Institutions in Sikka Regency

a. Take a religious and family approach

The Ukhuwah Islamiyah ties of Muslims in Sikka Regency are very strong. This is caused by Muslims in Sikka Regency who are a minority. Realizing themselves as a minority, the solidarity of Muslims in Sikka Regency can be said to be quite high. Communication between mosque administrators, PHBI, preachers throughout Sikka Regency is very good.

Ukhuwah nashabiyah or family ties in Sikka Regency can be said to be very close. This is because the Sikka Regency Muslims are families of the same ethnic or ethnic group who gather and establish settlements based on ethnicity and kinship. Like the island of Parmaan, Nanghale village, Kampung Ndete, Waturia, which is a settlement that is occupied by almost one hundred percent of the Bajo tribe. Whereas Pemana island, Likong Gete village and Buton 
village are occupied by almost one hundred percent of the Buton tribe. There are also settlements where the majority of the population are Makassar Bugis such as Kampong Beru, Pemo Pombo and Geliting.

This association was very well understood by the Muhammadiyah management and made it a major weapon in developing the Muhammadiyah missionary movement. When going to establish a Muhammadiyah branch or branch, or business charity, in a village, then the one in charge of lobbying is the administrator who has a familial bond with the people in the village. As when opening the PCM Parumaan, MIS Muhammadiyah Parumaan, PCM Wuring and MIS Muhammadiyah Wuring, because most residents of the Wuring village are Bajo people, then the one in charge of lobbying is Pak Mudjir who is a Bajo person and born in Wuring.

\section{a. Exemplary}

Exemplary is one of the keys to the success of the Muhammadiyah Regency of Muhammadiyah and the principals of Muhammadiyah schools in developing Muhammadiyah business charities in Sikka Regency. Each board and principal always tries to set a good example for teachers and students, both in terms of discipline, hard work, sincerity and sacrifice. With this example, teachers and students are motivated to fight together to advance the charitable efforts of Muhammadiyah. With the example, the principal is easy to give direction to the teacher and students. 
Likewise, the teacher and students will be happy to accept every direction the school principal sees because the principal has already carried out what was ordered by the principal.

\section{b. Sacrificing}

Success always requires sacrifice. Without sacrifice, success cannot be achieved. This was fully realized by the Muhammadiyah trustees of Sikka Regency. To develop the wing of the company or to set up a business charity, the Muhammadiyah trustees are aware that they must be willing to sacrifice everything they have, ranging from energy, training, wealth, time and even feelings. As told by Haji Badri and Haji Pattahere, two Muhammadiyah figures in Nangahale founded the MIS Muhammadiyah and MTs Muhammadiyah Nangahale.

Seeing the fact that in Nangahale (a Muslim settlement established by the government to accommodate Bajo people from the island of Parumaan who were affected by the devastating earthquake and tsunami waves in 1992) there were no schools at elementary or junior high level, arousing the hearts and minds of Hajj Badri and Hajj Pattahere to establish an Islamic school specifically for Bajo children. So Haji Badri sacrificed his building which was used as a storehouse for salt, seaweed, copra and other commodities. After the warehouse was given a bulkhead, but it was not enough, Haji Badri again sacrificed one of his houses to become a classroom.

Souls that want to sacrifice are also owned by every Muhammadiyah school teacher. Every Muhammadiyah 
school has a story about the sacrifice of its teacher. Like MIS Muhammadiyah Parumaan and MIS Persyarikatan Pangabatang, whose teachers must commute crossing the ocean every day to teach by using their own boat, they must struggle with big waves, strong winds and even heavy rain. Likewise, teachers who live on land but are far from school, must go back and forth to school using a motorcycle taxi that costs more than the salary earned from school. In fact, there is a teacher from MIS Muhammadiyah Nangahale who continues to commute teaching with a distance of home to school about thirty kilometers even though she was pregnant and just asked for permission to give birth on the day she gave birth.

c. Super smart budget management and assistance

Super smart financial management and assistance are other factors for the success of Muhammadiyah's association in Sikka Regency in developing its business charity in the field of education. An example in this case is MTs Muhammadiyah Nangahale. Thanks to the principal's ability to manage the budget, this school can have drum band equipment and equipment for sixty million rupiah. When the MTs Muhammadiyah Nangahale drum band performed at the Republic of Indonesia Anniversary commemorative event held at the Talibura District level, other school principals congratulated the MTs Muhammadiyah Nangahale school principal because they felt that being able to hold a drum band at school was not easy and not cheap. They conveyed their 
congratulations because they as a school that has long been established compared to MTs Muhammadiyah Nangahale, were unable to hold a drum band.

\section{Conclusion}

The Muhammadiyah congregation first came into contact with residents of Sikka Regency in 1937, and was taken to Geliting (a Muslim village of Makassar, Bugis and Bajo ethnic groups located in Kewapante District, Sikka Regency) by Mr. Husaini Daeng Maramba. He is from Selayar, South Sulawesi). Awareness of the importance of the union continued to be developed in the years that followed, in 1952, 1960, 1985 was the culmination of its development, finally the Muhammadiyah Association began to explore the founding of Muhammadiyah High School.

In connection with the development of the Muhammadiyah Association in Sikka Regency, it is actually inseparable from the methods carried out until finally it is able to provide significant changes. These changes were made using several methods, namely: methods of development in the social field. In this field the management of skilled and broad-minded human resources is emphasized by creating various fields, one of which is education and social institutions. The second method is the development in the fields of economics, the field of religion as well as the one that best describes the supremacy of the field is education.

In the development of Muhammadiyah educational institutions in Sikka District, several approaches that were also 
successful in such institutions were religious approaches in the family, exemplary approaches, sacrifice of the branch leaders by making the land and houses available for education and school buildings, and for managing the budget. and help with super smart

\section{REFERENCES}

AUM Berkemajuan Berspirit Al Maun”, Suara Muhammadiyah. Edisi 7, Tahun ke 103. Yogyakart, 2018.

Hadjid, Pelajaran KHA. Dablan: Muhammadiyah Falsafah Ajaran \& 17 Kelompok Ayat Al-Qur'an (Warisan Intelektual KHA. Dablan Yang Ditulis Oleh Murid Termudanya). Cet. III; Yogyakarta: LPI PPM, 2008.

Misi Penting Amal Usaha Muhammadiyah", Suara Mubammadiyah. Edisi 7, Tahun ke 103. Yogyakart, April 2018.

Nashir Haedar, Kuliah Kemubammadiyahan 1. Cet. I; Yogyakarta: Penerbit Suara Muhammadiyah, 2018.

Qodir Zuly, Muhammadiyah Studies: Reorientasi Gerakan dan Pemikiran Memasuki Abad Kedua. Cet. V; Yogyakarta: Kanisius, 2014.

Rajiah Siti Rusydi, Peran Muhammadiyab: Konsep Pendidikan, Usaha-usaha di Bidang Pendidikan, dan Tokoh, Jurnal Tarbawi| 1 |No 2 (tth.). 
Ibnu Mas'ud

Setiawan Farid, Genologi dan Modernisasi Sistem Pendidikan Mubammadiyah 1911-1942.

Tim Penulis Buku Pedoman AIK, Al-Islam dan Kemubammadiyahan. Edisi 1; Malang: UMM Press, 2012. 